\title{
Molecular half-full mechanisms by phagocityc cells on invasive Aspergilosis
}

\section{Mecanismos moleculares mediados por células fagocíticas en la aspergilosis invasiva}

\author{
Karla Rossanet Dzul-Rosado,MSc ${ }^{1}$, Viridiana Martínez-Campos, QFB ${ }^{2}$, \\ Gaspar Peniche-Lara, MSc $^{3}$, Jorge E. Zavala-Castro, PhD $^{1}$
}

\section{Summary}

Fungus from the Aspergillus genus mainly affects lung tissue, occurring when the integrity of the host immune system is compromised. The human body uses immunocompetence conditions from mechanical and enzymatic defenses and the action of the innate immune system cells and also uses adaptive responses to control infection. Neutrophils, macrophages, and dendritic cells are critical as antifungal effector cells possess surface receptors that recognize fungal structures and trigger specific responses. TLRs and Dectin-1 the most studied for this interaction. TLRs are responsible for the production and release of cytokines and Dectin-1 is essential in the phagocytosis of the particle recognition and production of ROS. The best-studied cytokines and its crucial role in the response to Aspergillus spp. are TNF- $\alpha$, IFN- $\gamma$, and IL-12. In this work, we reviewed the main mechanisms related to molecular receptors on phagocytic cells involved in the recognition of Aspergillus spp. Understanding the immune response in situations of immunocompetence and its comparison in immunodeficient organisms could provide alternatives to control invasive aspergillosis.

Keywords: Aspergillus; Immune system; Toll-like receptors; Dectin-1; DC-SIGN; MR and cytokines.

Colomb Med. 2012; 43: 95-102

\section{Resumen}

Los hongos del género Aspergillus afectan sobre todo al tejido pulmonar, presentándose cuando la integridad del sistema inmune del hospedero se ve comprometida. El organismo en condiciones de inmunocompetencia se vale para controlar la infección tanto de defensas mecánicas, enzimas y la acción de células del sistema inmune innato y respuestas adaptativas. Los neutrófilos, macrófagos y células dendríticas son de fundamental importancia como células efectoras antifúngicas, poseen receptores de superficie como TLR, Dectina-1, DC-SIGN y receptor de manosa (MR) que reconocen estructuras micóticas y desencadenan respuestas específicas. TLR y Dectina-1, son los más estudiados para esta interacción. Los TLR son los responsables de la producción y liberación de citocinas y Dectina1 es fundamental en la fagocitosis de la partícula reconocida y la producción de ROS. DC-SIGN es el receptor esencial para el reconocimiento de las esporas de Aspergillus spp. por células dendríticas y macrófagos, y se encuentra presente en células pulmonares con actividad fagocítica. El MR reconoce estructuras micóticas después de la internalización del hongo y promueve la liberación de una amplia variedad de citocinas. Las citocinas mejor estudiadas y cuyo papel es crucial en la respuesta contra Aspergillus spp. son TNF- $\alpha$, IFN- $\gamma$ e IL-12. En el presente trabajo, se revisaron los

Profesor Investigador Titular, Centro de Investigaciones Regionales Dr. Hideyo Noguchi, Universidad Autónoma de Yucatán, Mérida, México.e-mail: karla.dzul@uady.mx_zcastro@uady.mx

2 Assistant research, Centro de Investigaciones Regionales Dr. Hideyo Noguchi, Universidad Autónoma de Yucatán, Mérida, México. e-mail: chavymtz@hotmail.com

Profesor Investigador Asociado, Unidad Interinstitucional de Investigación Clínica y Epidemiológica, Facultad de Medicina, Universidad Autónoma de Yucatán, Mérida, México. e-mail: gaspar.peniche@uady.mx

Received for publication May 6, 2011 Accepted for publication November 11, 2011 
principales mecanismos moleculares relacionados con los receptores presentes en las células fagocíticas implicadas en el reconocimiento de Aspergillus spp. La comprensión de la respuesta inmune en situaciones de inmunocompetencia y su comparación en organismos inmunodeficientes podría proporcionar alternativas que permitan el control de la aspergilosis invasiva.

Palabras clave: Aspergillus; Sistema inmune; Receptores Toll-like; Dectina-1; DC-SIGN; MR y citocinas.

\section{Colomb Med. 2012; 43: 95-102}

The medical advances in the 1990s have led to greater longevity of the population, as well as to a greater number of patients with some type of organ transplant, chemotherapy as a means of combating neoplasia, or an increase in patients on immunosuppressive regimens, which also increased the number of patients with different degrees of immunosuppression. This condition has led to the development of opportunistic infections, particularly those caused by fungi, which cannot be limited to local infection, but also get to spread to a systemic infection, such as invasive aspergillosis (IA) ${ }^{1}$.

$\mathrm{AI}$ is the most common fungal disease in neutropenic patients and has increased progressively, mainly involves the invasion and involvement of the lung tissue, and has become the leading cause of opportunistic fungal infection by filamentous fungi and death in patients with hematologic diseases. Its mortality rate ranges between 40 and $90 \%$ in highrisk $^{2-4}$. This infection is mainly favored by the inability of the immune system to limit the infectious process, which becomes rapid in evolution and its clinical manifestations are nonspecific and atypical, making diagnosis difficult. Therefore, requiring establishment of treatment regimens that sometimes generate repercussions to the patient's health.

\section{Immune defense against invasive aspergillosis (IA)}

The main route of infection is inhalation of spores in the air, followed by deposition in the bronchioles or alveolar spaces ${ }^{5,6}$. The spores are inhaled, trapped in mucus, and then actively transported by the motion of the cilia to the oropharynx, where they are ingested or expelled through expectoration ${ }^{6}$.

Mechanical defenses, including the cough reflex and sneezing help expel particles inhaled ${ }^{7}$. Cells in the respiratory tract produce large numbers of molecules with antimicrobial activity, some of which have antifungal activity against $A$. fumigatus. Such is the case of lactoferrin produced by neutrophils and epithelial cells that bind iron and deprive the fungi of this element, which is essential for growth ${ }^{8}$.

Several enzymes play an important role as a defense against Aspergillus species. Elastase and cathepsin G are two serine proteases present in the azurophilic granules of neutrophils that have activity against Aspergillus ${ }^{9}$. Chitinases are produced by macrophages and epithelial cells are capable of degrading chitin, which is an essential component of $A$. fumigatus $^{10}$.

Neutrophils, macrophages and dendritic cells are critical as antifungal effector cells. In healthy subjects, spores not eliminated by mucociliary depuration are recognized by the alveolar macrophages from epitelium, which try to eliminate the spores or the damage they produce.

Additional effector cells are recruited to infection sites of infection by the action of inflammatory signals such as cytokines, chemokines and complement components ${ }^{11}$. Macrophages phagocyte spores and they can only destroy spores that are distended $^{12}$. The spores that escape the death of macrophages and germinate become the target of neutrophils, which are capable of destroying the hyphaer ${ }^{5}$.

Dendritic cells (DC) initiate innate and adaptive immune response of a wide range of microorganisms ${ }^{13}$. These cells capture and process antigens, express co-stimulatory molecules, migrate to lymphoid organs, and secrete cytokines that initiate immune responses and these $\mathrm{T}$ cells provide the appropriate signals $^{14,15}$. The differentiation of CD $4+T$ cells into T-helper cell (Th) type 1 (Th1) or type 2 (Th2) and the development of pathway-specific responses is a key 
determinant of susceptibility or resistance to invasive fungal infections. The predominance of Th1 responses on Th2-type correlate with protection against fungal infections ${ }^{16,17}$. The defense against invasion by $A$. fumigatus is impaired by the action of inflammatory cytokines (IL-4 and IL-10), whose depletion improves the elimination of spores ${ }^{18,19}$. High levels of IL-10 increase survival of the spores because they affect the respiratory burst in macrophages ${ }^{20}$. The proinflammatory cytokines IFN- $\gamma$ and TNF- $\alpha$, IL-12, IL-1, and IL- 6 play a protective role against the $\mathrm{AI}^{20}$ and are essential for optimal activation of phagocytosis at infection sites ${ }^{21}$. TNF- $\alpha$ and INF- $\gamma$ are critical components of innate immunity in both immunocompetent patients and those with some degree of immunosuppression. When macrophages are in contact with structures of $A$. fumigatus they mainly produce these cytokines, which are essential for recruitment of neutrophils in the lungs and also play an important role in epithelial cell response against $\mathrm{AI}^{22-26}$. The role of IL-12 in Th1 cell growth is linked to its ability to promote the production of INF- $\gamma$ and encourage expansion and survival of cells producing this cytokine. The production of IL-12 is linked to the response of alveolar macrophages from viable spores of $A$. fumigatus, dependent on $\mathrm{TLR}^{27}$. High levels of IL-10 affect the production of INF- $\gamma$ and have been detected in patients with aspergillosis and are associated to susceptibility of infection. However, this cytokine secretion by Treg cells could be a consequence rather than the cause of the infection ${ }^{27}$.

Likewise, other cells such as Th17 lymphocytes and Th regulators play an important role in infection with $A$. fumigatus. Th17 lymphocytes, a type of lymphocyte recently discovered characterized by the release of IL-17, are believed to be important in the immune response against pathogenic microorganisms including bacteria and fungi, as well as contributing to the development of autoimmune diseases ${ }^{28}$. Th17 responses have been implicated in immunity against fungi, suggesting that this type of response is required for the protection of $C$. albicans ${ }^{28,29}$. Dectin-1 is involved in the generation of the protective response of IL-17 on Aspergillus fumigatus pulmonary infection ${ }^{30}$. Just as there is also evidence that DC-SIGN receptors, TLR2, and mannose receptor are involved in the production and modulation of Th17 responses $^{28,31,32}$. The inflammation present in these clinical pictures is controlled by expansion, activation and recruitment of regulatory Th cells, which can suppress neutrophil activity. Regulation is an essential component in the host response in infection and allergy to the fungus, but could be inhibited by it. Also, germination of conidia interferes with anti-inflammatory responses and activity of $\mathrm{T}$ lymphocytes regulators ${ }^{33}$.

\section{Phagocytosis in invasive aspergillosis}

Polymorphonuclear neutrophils (PMN) are the predominant immune cells in the acute phase of most fungal infections in different clinical situations and are essential for the eradication of pathogens ${ }^{34}$. The role of PMN in the innate immune system is the destruction of microorganisms, which is carried out through oxidative and non-oxidative mechanisms ${ }^{35}$.

Oxidative mechanisms involve ROS generation through the NADPH oxidase pathway, which produces superoxide and also through the MPO, which catalyzes the conversion of hydrogen peroxide and superoxide to hypochlorous acid and hydroxyl radicals. The neutrophil granules contain cationic peptides, which are part of the non-oxidative mechanisms of microbial killing directly, plus they produce a wide variety of cytokines and chemokines ${ }^{35}$.

The phagocytes produce TNF- $\alpha$ in response to different morphological structures of Aspergillus, but production of IL-12 is linked to the internalization of the spores; whereas, IL-4 and IL-10 is produced only by phagocytosis hyphae of the fungus ${ }^{36}$.

\section{Cell wall composition of Aspergillus spp.}

The cell wall of Aspergillus spp. is comprised mainly of polysaccharides, which are divided into two groups depending on their solubility in alkaline solutions. The alkali-insoluble fraction, believed 
responsible for the rigidity of the cell wall is composed of linear $\beta$-glucans and $\beta$-(1.3)/(1.4)-glucans, which had not been described in any other fungus, as well as GM, chitin, and $\beta$-(1,3)-glucans $(B G)$ as major components $^{37,38}$. The BG are involved in pathogenassociated molecular pattern (PAMP) recognition of Aspergillus spp., stimulate and prolong PMN adherence, as well as stimulate the respiratory burst by these cells ${ }^{39}$.

The innate immune system does not respond to the inactive or resting spores of Aspergillus and responses occur only when the spores are in the process of germination ${ }^{22,23,40,41}$ because the remodeling and expansion of the cell wall spores during germination results in the exposure of $\beta$-glucans present in fungi ${ }^{41}$.

\section{Receptors}

The main receptor involved in recognizing BG in Aspergillus in myeloid cells is the receptor called Dectin- $1^{42}$. There is evidence that TLRs and MR are involved in the production of inflammatory responses against Aspergillus infection. Like TLRs that initiate these responses ${ }^{23,43}$, DC-SING also plays an important role in the AI to be essential for the initiation of the adaptive response.

\section{Toll-like receptors (TLR)}

In PMN, TLRs are activated by different mechanisms and play an important role in controlling the functions of phagocytic cells in fungal infection. TLRs involved in host defense against $A$. fumigatus are TLR2, TLR4, and TLR9, which recognize zymozano, mannans, and fungal DNA. Clearly, the role of TLR2 and TLR4 in recognizing Aspergillus and structures in triggering responses that cause the release of proinflammatory cytokines ${ }^{27,40}$.

CD14, TLR2, TLR4, and the adapter protein MyD88 play an important role in immune responses of mouse peritoneal macrophages and human monocytes, against different growth phases of $A$. fumigatus $^{44}$. Signaling by TLR2 to produce TNF-á is predominantly on TLR4 in the development of a response against Aspergillus infection ${ }^{44,45}$. TLR2 plays a greater role than TLR4 in the phagocytosis of $A$. fumigatus $^{46}$. The response from TLR4 is effective against germ spores of this fungus, but does not have the ability to recognize hyphae; unlike TLR2, which does not decrease cytokine production in response to different growth phases of Aspergillus in macrophages $^{45}$. In the absence of TLR2 and MyD88 inflammatory cytokine production is not triggered; however, TLR2 and MyD88 are not required for phagocytosis and ROS production in response to zymosan, given that in the absence of these molecules there is still release of ROS and phagocytosis of these particles, suggesting mechanisms independent of TLR2 and MyD88 in the production of ROS and mediated phagocytosis ${ }^{43}$.

\section{Dectin-1}

Dectin-1 is a highly expressed receptor in various populations of myeloid cells, particularly monocytes, macrophages, neutrophils, and dendritic cells also found in a population of $T$ cells in which expression is low, additionally, it is expressed in the $\mathrm{B}^{48}$ lymphocyte.

Dectin-1 receptors are the predominant PRR in the recognition of a wide variety of ligands $\beta-1,3$ and $\beta-1,6$ glucan of fungi and plants ${ }^{22,49,50}$, which have been implicated in the recognition and phagocytosis of different yeasts and filamentous fungi by using a $\beta$ dependent recognition glucans present in the cell wall of these microorganisms ${ }^{51}$.

The Dectin-1 receptor is required for defense against Aspergillus; the first evidence of the in vivo role ofDectin-1 receptors in the recognition of $A$. fumigatus was reported in a study that assessed the production of proinflammatory cytokines after co-culture of alveolar macrophages with $A$. fumigatus alive and competitive carbohydrate monoclonal antibodies or receptor blocking Dectin- $1^{22}$.

The results were the reduction of inflammatory 
responses, especially the production of proinflammatory cytokines: TNF- $\alpha$, IL-1 $\alpha$, IL-1 $\beta$, IL6, macrophage inflammatory protein 2 (MIP2), macrophage inflammatory protein $1 \alpha$ (MIP-1 $\alpha)$, GCSF and GM-CSF, and decreased recruitment of neutrophils ${ }^{22,30}$. These receptors are important in alveolar macrophages in the induction of Th1-type responses for host defense against optimal Aspergillus infection. Th1 lymphocytes, when stimulated with Aspergillus, produce IFN- $\gamma^{23}$. It has been established that $\beta$-glucan recognition by Aspergillus receptor Dectin-1 is an important cofactor triggering inflammatory responses via TLR2. In macrophages, the cooperative role of Dectin-1 and TLR2 is required for TNF- $\alpha$ production in response to the recognition of fungal structures, and the first demonstration of interaction between TLR and other PRR ${ }^{23}$.

Although Dectin-1 results in increased inflammatory responses produced by the recognition of TLR2 in macrophages and dendritic cells mediated by this recognition, the receiver is not capable of producing these responses alone. The dectin-1 receptor can form phagosomes; this activity increases in the presence of TLR2.

Alveolar macrophages lacking the expression of any of these receptors are more susceptible to infection by $A$. fumigatus, and the production of IL-1, TNF- $\alpha$, and MIP-1 is decreased resulting in an insufficient recruitment of neutrophils in the lung and uncontrolled fungal growth ${ }^{30}$. This is because the collaboration of these receptors occurs by parallel activation of Syk pathways and TLR/MyD88Dectin-1, resulting in the substantial degradation of $\mathrm{IkB}$. Deficiency of any of these proteins involves the abolition of collaborative responses to the production of TNF- $\alpha$, MIP-1, and MIP-2 ${ }^{42}$.

Recent studies indicate that the cooperative role of TLR and Dectin-1 is not restricted to TLR2, but that there is also collaboration from TLR4, TLR5, TLR7, and TLR9 ${ }^{52}$.

\section{DC-SING (Dendritic cell-specific ICAM-3- grabbing nonintegrin)}

DC-SING is a Type-II lecithin that functions as adhesion receptor. This receiver has the ability to interact with $A$. fumigatus spores, which like anti-DCSIGN are capable of inhibiting the binding of spores to dendritic cells. The clinical relevance of this interaction is emphasized by the presence of a DCSIGN receptor on lung dendritic cells and alveolar macrophages ${ }^{53}$.

The binding and internalization of $A$. fumigatus spores in dendritic cells is mediated by DC-SIGN through recognition of cell wall polysaccharides like the fungus. This receptor plays a critical role in the capture of $A$. fumigatus spores by dendritic cells, which is strengthened by its detection in alveolar macrophages and further suggests that this participation is done in the initial AI state ${ }^{53}$.

\section{Mannose receptor (MR)}

The MR is a receptor for endocytosis, which has a wide range of endogenous ligands such as antigens and microbial antigens, allowing participation in a wide variety of cellular processes including pathogen recognition and cell migration. Although this receptor induces a variety of cellular responses, the molecular mechanisms responsible for intracellular signal transduction are not clear. The recognition of fungi by this receptor could occur only after internalization of the fungus and promotes the production of cytokines such as TNF- $\alpha$, GM-CSF, IL-12, IL-8, IL-6, and IL-1 $\beta^{28,54}$.

The MR stimulation with Candida spp. is capable of inducing significant levels of IL-17, with Dectin1 and TLR2 able to amplify these responses ${ }^{28,32}$.

The structure recognition of $A$. fumigatus by the Dectin-1 receptor causes increased shedding of the mannose receptor ${ }^{54}$. 


\section{Internalization}

Phagocytosis of $A$. fumigatus spores by alveolar macrophages depends primarily on the degree of polymerization of actin at the site of contact between the spore and the macrophage. IP-3K, an indispensable element for the phagocytosis of these spores, can be carried out. It also requires phagolysosome acidifi-cation to eliminate spores ingested by the action of several ATPases, which accumulate in the phagosomal membrane during phagolysosome maturation $^{55}$.

\section{Respiratory burst}

Phagocytes respond to different stimuli through a phenomenon known as respiratory burst, which depends on nicotinamide adenine dinucleotide phosphate (NADPH) oxidase. After activation of macrophages and neutrophils, the cytosolic components of the NADPH oxidase system are translocated to join the membrane components; the enzyme complex catalyzes the production of superoxide anion because it accepts electrons from cytosolic NADPH and donates it to molecular oxygen found in the phagocytic vacuole; thereby, producing ROS. The activation of this enzyme complex is regulated by the influx of calcium released from cellular deposits through phosphorylation of $\mathrm{PKC}^{56}$.

ROS are essential for the elimination of $A$. fumigatus in alveolar macrophages and neutrophils ${ }^{12,35}$. The lack of a functioning NADPH oxidase system in optimal conditions allows the internalization of the spores of this organism, but lacks the capacity to eliminate them. It is further noted that the administration of corticosteroids prevents the eradication of Aspergillus spores by altering the mechanisms of ROS production ${ }^{12}$. The mechanism of ROS release is dependent on Syk in macrophages ${ }^{57}$; however, it requires only partial recognition of structures by receptor Dectin-1 in macrophages and neutrophils ${ }^{58}$. In contrast to the NADPH oxidase, inducible nitric oxide synthase (iNOS) ${ }^{12}$ and the $\mathrm{MPO}^{59}$ do not play an important role in the elimination of $A$. fumigatus.

\section{Conclusion}

Opportunistic mycoses like AI are affections that produce severe clinical damages in immunocompromised patients in whom the prognosis is unfavorable. Currently, there is information about the mechanisms of the immune system to deal with these infections.

In the innate immune system, responses to AI phagocytic cells, macrophages, neutrophils, and dendritic cells are predominantly involved, and these are the link between innate and adaptive immunity. Phagocytic cells have mechanisms activated in response to contact with Aspergillus. MR, DC-SIGN, TLR2, and Dectin-1 receptors are essential in the recognition of Aspergillus structures on the cell surface of phagocytes.

Dectin-1 is required for the internalization of fungus and production of ROS; it is necessary to control Aspergillus structures in the body. TLR2 triggers the production of proinflammatory cytokines. These cytokines promote the eradication of infection through cell recruitment to the infection site and activation of adaptive responses. Although the role of Dectin-1 and TLR2 is essential in the response to the AI, other receptors such as DC-SIGN and MR play an important role in all of these receptors being critical to the resolution of the infection. The fundamental problem in patients with $\mathrm{AI}$ is that the immune system is compromised and the body's own response is poor; however, because phagocytic cells are the first contact of the fungus with the host; these cells constitute an attractive research area.

Understanding their roles and mechanisms could be key to provide empowering strategies to modulate the response of the host phagocytes and allow resolving the infection.

Conflict of interest. No potential conflict of interest exists in this manuscript. If any, these will be declared in this document and/or explained in the title page, identifying funding sources. 


\section{References}

1. Lumbreras C, Gavaldà J. Aspergilosis invasora: manifestaciones clínicas y tratamiento. Rev Iberoam Micol. 2003; 20:7989.

2. Patterson TF, Kirkpatrick WR, White M, Hiemenz JW, Wingard JR, Dupont B, et al. Invasive aspergillosis. Disease spectrum, treatment practices, and outcomes. I3 Aspergillus Study Group. Medicine. 2000; 79: 250-60.

3. Lin SJ, Schranz J, Teutsch SM. Aspergillosis case-fatality rate: systematic review of the literature. Clin Infect Dis. 2001; 32: 358-66.

4. Silva RF. Infecções fúngicas em imunocomprometidos. Capítulo 8. J Bras Pneumol. 2010; 36: 142-7.

5. Latge JP. Aspergillus fumigatus and aspergillosis. Clin Microbiol Rev. 1999; 12: 310-50.

6. Dagenais TRT, Keller NP. Pathogenesis of Aspergillus fumigatus in invasive aspergillosis. Clin Microbiol Rev. 2009; 22: 447-65.

7. Balloy V, Chignard M. The innate immune response to Aspergillus fumigatus. Microbes Infect. 2009; 11: 919-27.

8. Zarember KA, Sugui JA, Chang YC, Kwon-Chung KJ, Gallin JI. Human polymorphonuclear leukocytes inhibit Aspergillus fumigatus conidial growth by lactoferrinmediated iron depletion. J Immunol. 2007; 178: 6367-73.

9. Tkalcevic J, Novelli M, Phylactides M, Iredale JP, Segal AW, Roes J. Impaired immunity and enhanced resistance to endotoxin in the absence of neutrophil elastase and cathepsin G. Immunity. 2000; 12: 201-10.

10. Chen L, Shen Z, Wu J. Expression, purification and in vitro antifungal activity of acidic mammalian chitinase against Candida albicans, Aspergillus fumigatus and Trichophyton rubrum strains. Clin Exp Dermatol. 2009; 34: 55-60.

11. Shoham S, Levitz SM. The immune response to fungal infections. BrJ Haematol. 2005; 129: 569-82.

12. Philippe B, Ibrahim-Granet O, Prevost MC, GougerotPocidalo MA, Sánchez-Pérez M, Van der Meeren A, et al. Killing of Aspergillus fumigatus by alveolar macrophages is mediated by reactive oxidant intermediates. Infect Immun. 2003; 71: 3034-42.

13. Huang Q, Liu D, Majewski P, Schulte LC, Korn JM, Young $\mathrm{RA}$, et al. The plasticity of dendritic cell responses to pathogens and their components. Science. 2001; 294: 870-5.

14. Romani L. Immunity to fungal infections. Nat Rev Immunol. 2004; 4: 11-24.

15. Banchereau J, Steinman RM. Dendritic cells and the control of immunity. Nature. 1998; 392: 245-52.

16. Roilides E, Tsaparidou S, Kadiltsoglou I, Sein T, Walsh TJ. Interleukin-12 enhances antifungal activity of human mononuclear phagocytes against Aspergillus fumigatus: implications for a gamma interferon-independent pathway. Infect Immun. 1999; 67: 3047-50.

17. Romani L, Mencacci A, Tonnetti L, Spaccapelo R, Cenci E,
Puccetti P, et al. IL-12 is both required and prognostic in vivo for $\mathrm{T}$ helper type 1 differentiation in murine candidiasis. $J$ Immunol. 1994; 153: 5167-75.

18. Cenci E, Mencacci A, Del Sero G, Bacci A, Montagnoli C, d'Ostiani CF, et al. Interleukin-4 causes susceptibility to invasive pulmonary aspergillosis through suppression of protective type I responses. J Infect Dis. 1999; 180: 1957-68.

19. Del Sero G, Mencacci A, Cenci E, d'Ostiani CF, Montagnoli $\mathrm{C}$, Bacci A, et al. Antifungal type 1 responses are upregulated in IL-10-deficient mice. Microbes Infect. 1999; 1: 1169-80.

20. Roilides E, Dimitriadou A, Kadiltsoglou I. IL-10 exerts suppressive and enhancing effects on antifungal activity of mononuclear phagocytes against Aspergillus fumigatus. $J$ Immunol. 1997; 158: 322-9.

21. Romani L, Puccetti P, Bistoni F. Interleukin-12 in infectious diseases. Clin Microbiol Rev. 1997; 10: 611-36.

22. Steele C, Rapaka RR, Metz A, Pop SM, Williams DL, Gordon S, et al. The beta-glucan receptor dectin-1 recognizes specific morphologies of Aspergillus fumigatus. PLOS Pathog. 2005; 1: e42.

23. Gersuk GM, Underhill, David M, Zhu L, Marr KA. Dectin1 and TLRs permit macrophages to distinguish between different Aspergillus fumigatus cellular states. J Immunol. 2006; 176: 3717-24.

24. Mehrad B, Strieter RM, Standiford TJ. Role of TNF-alpha in pulmonary host defense in murine invasive aspergillosis. J Immunol. 1999; 162: 1633-40.

25. Bellanger AP, Millon L, Khoufache K, Rivollet D, Bieche I, Laurendeau I, et al. Aspergillus fumigatus germ tube growth and not conidia ingestion induces expression of inflammatory mediator genes in the human lung epithelial cell line A549. J Med Microbiol. 2009; 58: 174-9.

26. Brieland JK, Jackson C, Menzel F, et al. Cytokine networking in lungs of immunocompetent mice in response to inhaled Aspergillus fumigatus. Infect Immun. 2001; 69: 1554-60.

27. Romani L. Immunity to fungal infections. Nat Rev Immunol. 2011; 11: 275-88.

28. Vautier S, Sousa Mda G, Brown GD. C-type lectins, fungi and Th17 responses. Cytokine Growth Factor Rev. 2010; 21: 405-12.

29. Huang W, Na L, Fidel PL, Schwarzenberger P. Requirement of interleukin-17A for systemic anti-Candida albicans host defense in mice. J Infect Dis. 2004; 190: 624-31.

30. Werner JL, Metz AE, Horn D, Schoeb TR, Hewitt MM, Schwiebert LM, et al. Requisite role for the dectin-1 betaglucan receptor in pulmonary defense against Aspergillus fumigatus. J Immunol. 2009; 182: 4938-46.

31. Zenaro E, Donini M, Dusi S. Induction of Th1/Th17 immune response by Mycobacterium tuberculosis: role of dectin-1, Mannose Receptor, and DC-SIGN.J Leukoc Biol. 2009; 86: 1393-401.

32. van de Veerdonk FL, Marijnissen RJ, Kullberg BJ, Koenen HJ, Cheng SC, Joosten I, et al. The macrophage mannose 
receptor induces IL-17 in response to Candida albicans. Cell Host Microbe. 2009; 5: 329-40.

33. Montagnoli C, Fallarino F, Gaziano R, Bozza S, Bellocchio $\mathrm{S}$, Zelante $\mathrm{T}$, et al. Immunity and tolerance to Aspergillus involve functionally distinct regulatory $T$ cells and tryptophan catabolism. J Immunol. 2006; 176: 1712-23.

34. Dubourdeau M, Athman R, Balloy V. Aspergillus fumigatus induces innate immune responses in alveolar macrophages through the MAPK pathway independently of TLR2 and TLR4. J Immunol. 2006; 177: 3994-4001.

35. Feldmesser M. Role of neutrophils in invasive aspergillosis. Infect Imm. 2006; 74: 6514-6.

36. Bozza S, Gaziano R, Spreca A, Bacci A, Montagnoli C, di Francesco $\mathrm{P}$, et al. Dendritic cells transport conidia and hyphae of Aspergillus fumigatus from the airways to the draining lymph nodes and initiate disparate Th responses to the fungus. I Immunol. 2002; 168: 1362-71.

37. Bernard M, Latge JP. Aspergillus fumigatus cell wall: composition and biosynthesis. Med Mycol. 2001; 39 Suppl 1: 9-17.

38. Fontaine T, Simenel C, Dubreucq G, Adam O, Delepierre $\mathrm{M}$, Lemoine J, et al. Molecular organization of the alkaliinsoluble fraction of Aspergillus fumigatus cell wall. $J$ Bioll Chem. 2000; 275: 27594-607.

39. Lavigne LM, Albina JE, Reichner JS. Beta-glucan is a fungal determinant for adhesion-dependent human neutrophil functions. J Immunol. 2006; 177: 8667-75.

40. Meier A, Kirschning CJ, Nikolaus T, Wagner H, Heesemann J, Ebel F. Toll-like receptor (TLR) 2 and TLR 4 are essential for Aspergillus-induced activation of murine macrophages. Cell Microbiol. 2003; 5: 561-70.

41. Hohl TM, Van Epps HL, Rivera A, Morgan LA, Chen PL, Feldmesser M, et al. Aspergillus fumigatus triggers inflammatory responses by stage-specific beta-glucan display. PLoS Pathog. 2005; 1: e30.

42. Brown GD, Herre J, Williams DL, Willment JA, Marshall AS, Gordon S. Dectin-1 mediates the biological effects of beta-glucans. J Exp Med. 2003; 197: 1119-24.

43. Gantner BN, Simmons RM, Canavera SJ, Akira S, Underhill DM. Collaborative induction of inflammatory responses by dectin-1 and Toll-like receptor 2. J Exp Med. 2003; 197: 1107-17.

44. Mambula SS, Sau K, Henneke P, Golenbock DT, Levitz SM. Toll-like receptor (TLR) signaling in response to Aspergillus fumigatus. J Biol Chem. 2002; 277: 39320-6.

45. Netea MG, Warris A, Van der MeerJW, Fenton MJ, VerverJanssen TJ, Jacobs LE, et al. Aspergillus fumigatus evades immune recognition during germination through loss of toll-like receptor-4-mediated signal transduction. I Infect Dis. 2003; 188: 320-6.

46. Luther K, Torosantucci A, Brakhage AA, Heesemann J, Ebel F. Phagocytosis of Aspergillus fumigatus conidia by murine macrophages involves recognition by the Dectin-1 beta-glucan receptor and Toll-like receptor 2. Cell Microbiol. 2007; 9: 368-81.

47. Taylor PR, Brown GD, Reid DM, Willment JA, MartínezPomares L, et al. The beta-glucan receptor, dectin-1, is predominantly expressed on the surface of cells of the monocyte/macrophage and neutrophil lineages. J Immunol. 2002; 169: 3876-82.

48. Willment JA, Marshall AS, Reid DM, Williams DL, Wong SY, Gordon S, et al. The human beta-glucan receptor is widely expressed and functionally equivalent to murine Dectin-1 on primary cells. Eur I Immunol. 2005; 35:1539-47.

49. Reid DM, Gow NA, Brown GD. Pattern recognition: recent insights from Dectin-1. Curr Opin Immunol. 2009; 21: 30-7.

50. Brown GD, Taylor PR, Reid DM, Willment JA, Williams DL, Martínez-Pomares L, et al. Dectin-1 is a major betaglucan receptor on macrophages. J ExpMed. 2002; 196:40712.

51. Brown GD, Gordon S. Immune recognition. A new receptor for beta-glucans. Nature. 2001; 413: 36-7.

52. Dennehy KM, Ferwerda G, Faro-Trindade I, Pyz E, Willment $\mathrm{JA}$, Taylor PR, et al. Syk kinase is required for collaborative cytokine production induced through Dectin-1 and Tolllike receptors. Eur J Immunol. 2008; 38: 500-6.

53. Serrano-Gómez D, Domínguez-Soto A, Ancochea J, Jiménez-Heffernan JA, Leal JA, Corbi AL. Dendritic cellspecific intercellular adhesion molecule 3-grabbing nonintegrin mediates binding and internalization of Aspergillus fumigatus conidia by dendritic cells and macrophages. $J$ Immunol. 2004; 173: 5635-43.

54. Gazi U, Rosas M, Singh S, Heinsbroek S, Haq I, Johnson S, et al. Fungal recognition enhances mannose receptor shedding through dectin-1 engagement. J Biol Chem. 2011; 286: 78229 .

55. Ibrahim-Granet O, Philippe B, Boleti H, Boisvieux-Ulrich E, Grenet D, Stern M, et al. Phagocytosis and intracellular fate of Aspergillus fumigatus conidia in alveolar macrophages. Infect Immun. 2003; 71: 891-903.

56. Cathcart MK. Regulation of superoxide anion production by NADPH oxidase in monocytes/macrophages: contributions to atherosclerosis. Arterioscler Thromb Vasc Biol. 2004; $24: 23-8$.

57. Underhill DM, Rossnagle E, Lowell CA, Simmons RM. Dectin-1 activates Syk tyrosine kinase in a dynamic subset of macrophages for reactive oxygen production. Blood. 2005; 106: 2543-50.

58. Taylor PR, Tsoni SV, Willment JA, Dennehy KM, Rosas M, Findon $\mathrm{H}$, et al. Dectin-1 is required for beta-glucan recognition and control of fungal infection. Nat Immunol. 2007; 8: 31-8.

59. Aratani Y, Kura F, Watanabe H, Akagawa H, Takano Y, Suzuki $\mathrm{K}$, et al. in vivo role of myeloperoxidase for the host defense. Jpn J Infect Dis. 2004; 57: S15. 